\title{
ORGANIZATION OF PRESCHOOL EDUCATION IN UKRAINE: METHODICAL SUPPORT
}

\author{
Tetiana Shynkar \\ Lecturer at the Department of Preschool Education of Pedagogical Institute, \\ Boris Grinchenko Kyiv University, Ukraine \\ e-mail: t.shynkar@kubg.edu.ua,orcid.org/0000-0002-5656-2032
}

\section{Summary}

The success of a preschool institution depends on the level of professional and pedagogical competence of preschool teachers. Therefore, the primary task is high-quality methodical support - providing systematic, timely assistance to teachers. Despite a number of research studies and the existing focus of attention to the problem of methodical support in educational institutions, there are currently almost no scientific studies devoted to the current state of the problem and its ways of reform. The analysis of periodicals of Ukraine is made, which is a reference point in the methodical work, contains useful recommendations, answers to important questions, tools for working with children, and is authoritative among teachers of the first link of education. The author specifies the approaches to aspects of methodical support in modern preschool educational institutions of Ukraine, namely: planning of methodical work; the image of the methodologist; use of innovative and interactive methodical forms in professional training of teachers.

Keywords: preschool educational institution, methodical work, methodical service, methodologist, periodical.

\section{DOI: https://doi.org/10.23856/3867}

\section{Introduction}

In modern conditions of education restructuring there is a need to change approaches to the activities of the methodical service in general and the organization of methodical support of preschool education in particular. Obviously, there should be a constructive and analytical review of the basic approaches, concepts, positions and strategies for the role, main tasks and functions of methodical support of preschool education. The National Doctrine of Education Development of Ukraine in the $21^{\text {st }}$ century and the Law "On Preschool Education" identify priority areas for the development of preschool education, focusing on the need for its scientific and methodical support, introduction of new educational technologies, updating educational programs and methodical support for preschool educational institutions.

General theoretical aspects of methodical support in educational institutions are clarified in the works of I. Zhernosek, S. Maidanenko, V. Pavlenko, etc.; the content, forms and features of the organization of methodical work in modern preschool educational institutions are revealed in the works of Ya. Bentsyon, H. Bielienka, K. Bila, A. Bohysh, O. Dolynna, I. Zhernosek, N. Havrysh, O. Kononko, V. Kryzhko, K. Krutii, A. Morozova, N. Savinova, L. Shvaika and others.

\section{The concept of methodical support}

Methodical support is a multifaceted concept involving a number of important tasks in preschool educational institution. Before identifying effective steps towards restructuring, we outline the conceptual apparatus. 
Support is an action with the meaning "to go near" (Velykyi tlumachnyi slovnyk suchasnoi ukrainskoi movy, 2001).

Methodical support is a holistic systematic interaction of a methodologist and a teacher, aimed at helping to choose the most optimal way to solve a professional problem based on their professional and life experience in the conditions of a concrete educational institution (Kylynych, 2016).

Methodical service is a complex pedagogical system, which is an integral part of the system of professional development of teachers without leaving the main place of work.

Methodical work is a system of interrelated activities aimed at improving the pedagogical skills of preschool teachers, preschool specialists, the development of their creative potential, which greatly contributes to the growth of education and politeness of children (Metodychnyi kabinet u dytiachomu sadku, 2008: 101).

Methodical work is a systematic collective and individual activity of teachers, aimed at improving their qualification and professional skills (Shvaika, 2007: 152).

Methodical support in the preschool educational institution is provided by the director of the institution and the methodologist. Their task is to use accessible and at the same time effective methods of improving pedagogical skills, which will encourage teachers to improve their professional level, will enrich their pedagogical experience, will form their skills of independent analysis of their own professional competence.

Methodologist comes from the term "methodology", a teacher with appropriate qualifications and pedagogical experience (Slovnyk inshomovnykh sliv, 1985).

Methodologist is a direct organizer of professional development of teachers, directs their self-education; organizational, methodological and managerial skills are important for the implementation of the main functions of methodologist (Zhernosek, Kolibabchuk, 2001).

The structural components of typical methodical work over the decades were: 1) group forms of methodical work (methodical associations of teachers, school for young preschool teachers, workshops, seminars, creative groups, counseling centers, pedagogical studios, interest clubs, etc.); 2) mass forms of methodical work (conferences, pedagogical readings, weeks of pedagogical skills, fairs of pedagogical ideas, methodical weeks, etc.); 3) individual forms of methodical work (internships, mentoring, independent work, consultations, competitions, elaboration of professional literature, etc.) (Zhernosek, Kolibabchuk, 2001).

H. Bielienka's (2001) views should be taken into account by methodologists when planning work with teachers: in a structured form the professional competence of a preschool teacher looks like a "three-step pyramid" which is based on professional knowledge, on the basis of which skills are formed; individualization and their interpretation by personality become the basis for the development of professional abilities.

\section{Regulatory and legal support}

Methodical support as an important component of preschool education is directly related to the level of its organization, which requires analysis of regulations.

Methodical work is an important indicator of the success of a preschool educational institution and one of the main ways to reform education, defined by the State National Program "Education" ("Ukraine of the $21^{\text {st }}$ century"), Laws of Ukraine "On Education", "On Preschool Education", "Basic Component of Preschool Education".

The Law of Ukraine "On Education" gives organizational, personnel and academic autonomy to each educational institution. The teaching staff is responsible for the process and 
result of the educational process of the preschool educational institution and methodical service in particular (Zakonodavstvo Ukrainy).

The Law of Ukraine "On Preschool Education" defines the tasks of scientific and methodical support of the preschool educational system and the structural departments of the education system of Ukraine that provide scientific and methodical support to the preschool education system:

- the central executive body that implements the state policy in the field of education, subordinated to it scientific and methodological institutions and higher pedagogical educational institutions, as well as research institutions of the National Academy of Pedagogical Sciences of Ukraine and the National Academy of Sciences of Ukraine;

- Central Institute of Postgraduate Pedagogical Education National Academy of Pedagogical Sciences of Ukraine;

- methodical offices and other scientific and methodical institutions subordinated to local education management bodies (Zakonodavstvo Ukrainy).

The activity of methodical support is concentrated in the methodical office of the preschool educational institution. The work of the methodical office is regulated by the Model Regulations on the methodical office of the preschool educational institution.

One of the tasks of methodical support is the implementation of internal monitoring of the quality of education in order to identify and track tendency in the development of the quality of education in the institution, establishing compliance of the actual results of educational activities within the state requirements for the content, the level of its volume of preschool education (Basic component of preschool education") to its stated goals, as well as assessing the degree, direction and causes of deviations from the goals (Ministerstvo osvity i nauky Ukrainy).

\section{Periodicals as a component of methodical support}

We believe that the components of methodical support in preschool education include publications of scientists and practitioners in periodicals of Ukraine, such as "Vykhovatel-metodyst doshkilnoho zakladu [Methodologist of preschool educational institution]", "Metodychna skarbnychka vykhovatelia [Methodical treasury of preschool teacher]", "Praktyka upravlinnia doshkilnym zakladom [Practice of preschool institution management]", "Doshkilne vykhovannia [Preschool education]", "Palitra pedahoha [Palette of the teacher]" and others.

Monthly, the only specialized magazine in Ukraine for methodologists of preschool educational institutions "Vykhovatel-metodyst doshkilnoho zakladu [Methodologist of preschool educational institution]" is a reference point in methodical work, contains useful recommendations, answers to important questions, tools for working with children. In particular, the following important issues are raised: Generalize pedagogical experience without mistakes (O. Staienna, 3, 2020); Methodical week, or Life hacks of methodical support of teachers (O. Polovina, N. Savinova, 12, 2018); Secrets of operational management for a methodologist (O. Sviatenko, 1, 2018); SWOT-analysis as a tool of strategic planning of methodical work (Ya. Draliuk, L. Hrynenko, 4, 2018); To the methodologist for the new school year: an excerpt from normative documents (N. Omelianenko, 9, 2017); Methodical form of work on improving the professional skills of preschool teachers (Yu. Tuzhenkova, 8, 2014); Professional reflection of a methodologist as a tool for correcting interaction with teachers (I. Kondratets, 10, 2014); Interactive forms of work with teachers in the intertest period (A. Kovalenko, 11, 2013); Interactive methods in the system of improving the professional skills of teachers (I. Kindrat, 6, 2012); Portfolio as a means of teacher self-improvement (M. Haliapa, 1, 2011), etc. 
The magazine "Metodychna skarbnychka vykhovatelia [Methodical treasury of preschool teacher]" is useful in creating your own methodical treasury of the preschool educational institution to design the educational process, taking into account the characteristics of preschool children and the potential of pedagogical staff. The pages of the magazine cover the issues of planning and organization of work with children, presentation of traditional and new forms of work with children in accordance with the educational lines of the Basic component of preschool education (new edition).

The specialized magazine for the head of the preschool educational institution "Praktyka upravlinnia doshkilnym zakladom [Practice of preschool educational institution management]" is useful not only in managerial activity, but also in methodical work as well. In particular, articles: Seminars, webinars or courses: is it possible to choose the form of advanced training "to your mind" (V. Bozhynskyi, 3, 2020); Educational program: to compose or not? (S. Nerianova, 10, 2019); The concept of development of pedagogical education: emphasis on practice (N. Omelianenko, 9, 2018); Methodical autonomy or execution according to instructions, or the right of an educational institution to choose a program (T. Nosacheva, 1, 2018); Educational platform - the environment for becoming a successful education manager (T. Pyroh, 4, 2017); Self-education of teachers (T. Hurkovska, 7, 2016), etc.

Magazines "Doshkilne vykhovannia [Preschool education]", "Palitra pedahoha [Palette of the teacher]" are also popular in Ukraine.

Researchers N. Havrysh and V. Zhelanova (2009) in the article "Understand another to get closer to yourself" propose to use videos of various forms of educational process, followed by the inclusion of teachers during training sessions in reflective-analytical activities. The authors believe that traditional forms of methodical work in preschool educational institutions, such as attending open classes and other forms of work have lost their professional development potential, the analytical aspect of this work has become purely formal, and the classes themselves have become a demonstration "show" of a preschool teacher's self-presentation.

O. Staienna (2020) in the article "Generalize pedagogical experience without mistakes" provides beginner methodologists with life hacks that will help structure the work and avoid mistakes in describing and presenting promising pedagogical experience.

As a result of the analysis of periodicals in Ukraine on preschool education, we can define approaches to aspects of activity of methodical support in modern institutions of preschool education: planning of methodical work; the image of the methodologist; use of innovative and interactive methodical forms in professional training of teachers.

\section{Conclusions}

Summarizing stated above, we can assume that high-quality methodical support should not provide methodical assistance, but create conditions for the development and improvement of pedagogical activities of the staff of preschool educational institution. Radical changes in the activities of the methodical service, in our opinion, lie in the plane of three vectors: reforming the structural system and directing the activities of the methodical service (shifting the emphasis in the implementation of methodical support for professional development of teachers); functional updating of the content and activity of the methodologist; the need to align traditional methodical forms of work with teachers and new challenges and contents of education. We consider the specified vectors of changes of activity of methodical service as perspectives of the further researches. 


\section{References}

Bielienka, H.V. (2011). Formuvannia profesiinoi kompetentnosti suchasnoho vykhovatelia doshkilnoho navchalnoho zakladu: monohrafia [Formation of professional competence of a modern educator of a preschool educational institution: monograph] - Kyiv: Universytet [in Ukrainian].

Velykyi tlumachnyi slovnyk suchasnoi ukrainskoi movy [Large explanatory dictionary of the modern Ukrainian language] (2001) Busel, V. (Ed.). Kyiv: VTF Perun [in Ukrainian].

Havrysh, H.V., Zhelanova, V. (2009) Zrozumity inshogo, shchob nablyzytys do sebe [Understand another to get closer to yourself] // Vykhovatel-metodyst doshkilnoho zakladu, 6: 7-13 [in Ukrainian].

Kylynych, O.A. (2020) Metodychnyi suprovid uprovadzennia innovatsiinykh tekhnolohii u navchalnyi protses [Methodical support of introduction of innovative technologies in educational process]. Retrieved from: http://nmc-pto.zp.ua/wp-content/uploads/2015/04/Kulinich-O.A._Metodychnyj-suprovid-uprovadzhennya-innovatsijnyh-tehnolohij-u-navchalnyj-protses.pdf (date of application: 28.04.2020) [in Ukrainian].

Metodychnyi cabinet u dytiachomu sadku [Methodical office in preschool institution] (2008). Kyiv: Shkilnyi svit [in Ukrainian].

Metodychna robota v DNZ [Methodical work in preschool educational institution] (2007) Shvaika, L.A. (Ed.). Kharkiv: Vyd. hrupa "Osnova” [in Ukrainian].

Nakaz ministerstva osvity i nauky Ukrainy "Pro zatverdzennia prymirnoho Polozhennia pro metodychnyi kabinet zakladu doshkilnoi osvity" [Order of the Ministry of Education and Science of Ukraine "On approval of the model Regulations on the methodical office of the preschool educational institution ”] № 372 (2018, April 14). Ministerstvo osvity i nauky Ukrainy. Retrieved from: https://mon.gov.ua/ua/npa/pro-zatverdzhennya-primirnogo-polozhennya-pro-metodichnij-kabinet-zakladu-doshkilnoyi-osviti (date of application: 15.03.2020) [in Ukrainian].

Slovnyk inshomovnykh sliv [Dictionary of foreign words] (1985) Melnychuk, O.S. (Ed.). Kyiv. Retrieved from: https://zakon.rada.gov.ua/laws/main/2628-14 (date of application: 02.05.2020) [in Ukrainian].

Staienna, O. (2020) Uzahalniuite pedahohichnyi dosvid bez pomylok [Generalize pedagogical experience without mistakes] // Vykhovatel-metodyst doshkilnoho zakladu, 3: 7-13 [in Ukrainian].

Zakon Ukrainy "Pro doshkilnu osvitu [Law of Ukraine “On Preschool Education”]. Zakonodavstvo Ukrainy. Retrieved from: https://zakon.rada.gov.ua/laws/main/2628-14 (date of application: 14.03.2020) [in Ukrainian].

Zakon Ukrainy "Pro osvitu" [Law of Ukraine "On Education”]. Zakonodavstvo Ukrainy. Retrieved from: https://zakon.rada.gov.ua/laws/show/2145-19 (date of application: 14.03.2020) [in Ukrainian].

Zhernosek, I.P., Kolibabchuk, V.I. (2001) Orhanizatsiia viddilom osvity naukovo-metodychnoi roboty $v$ raioni: navchalno-metodychnyi posibnyk [Organization of scientific and methodical work in the district by the department of education: Educational and methodical manual]. Kyiv [in Ukrainian]. 